\title{
Faculty-Librarian Collaboration in Building the Curriculum for the Millennium: The US Experience
}

\section{Hannelore B. Rader}

Hannelore Rader received her MLS from the University of Michigan, USA. She also has a BA in Russian and Spanish, and a Master's in German literature from the University of Michigan. Before becoming University Librarian at the University of Louisville in 1997, she was Director of the University Library at Cleveland State Library, a position she held for 10 years. She has served as consultant at the University of South Africa and USIS regarding information literacy in higher education in Pretoria, Durban, and Cape Town; and as consultant to the Hungarian Ministry of Education regarding academic libraries in Hungary. She is currently a member of the IFLA Standing Committee on University Libraries and other General Research Libraries. Ms Rader may be contacted at the University of Louisville Library, Louisville, Kentucky 40292, USA (fax: +(1-502) 8527394; e-mail: h.rader@louisville.edu).

[Ms Rader's paper was delivered during the 64th IFLA General Conference. Amsterdam, Netherlands, 16-21 August 1998 and updated for this issue of IFLA Journal.]

\section{Introduction}

A s higher education prepares for Athe 21st century enormous changes are occurring due to new technological developments and the need on the part of faculty and students to acquire computer and information skills. Learning now has to be continuous and almost a "way of being."I Universities must teach their constituents to integrate learning opportunities into everything they do in order to be successful in the constantly changing work environment, in organizational work and in society. Higher education needs to look closely at the business world where strategic advantages are now more and more based on learning and teaching organizations to take advantage of evolving technology, the Internet, the global marketplace and the new economy.?

In the United States the environment for higher education during the last decade has been strenuous. Funding agencies for universities and colleges have been more demanding in assessing higher education outcomes and faculty productivity. Competition for students both by publicly funded and private institutions has been strong. For-profit academic institutions like the University of Phoenix have added a new dimension to the changing highereducation environment. The demand for distance learning opportunities and the evolving virtual university have increased the strain on the already problematic academic environment. University administrators are being pressured by legislators and governing boards to perform miracles by doing more with less; producing more and better research; and graduating highlyemployable individuals.

Competition among colleges and universities although not new is growing stronger. Teaching, research and service, the three-part mission of universities and their libraries, are being reshaped, creating a climate for transformation and new opportunities. Similar to universities, libraries are restructuring to accommodate technological developments, changing information demands and learner needs.

\section{Higher Education in the} United States

There are more than 3,700 public and private institutions of higher learning in the United States, with enrollments of more than 15 million students of whom $70 \%$ are enrolled in public institutions at a cost of billions of dollars. These colleges and universities include more than 4,600 libraries with an inventory of more than 1.2 billion volumes.+

The cost of higher education both for individual students and institutions has continued to increase each year. For example. tuition cost has increased more than $200 \%$ since the 1980 s. Higher education is an expensive operation: it has become "big business". At the same time, state and federal support for higher education has become more limited. Legislators, governing boards and accrediting agencies are beginning to demand better assessment; measurable outcomes for graduates in terms of being competitive in the global market place; and higher productivity on the part of faculty in teaching and research.

In other words, outside pressure is being applied to higher education as never before to bring about changes commensurate with changes taking place in society. 
New models for universities are slowly beginning to emerge to address financial needs and competition. Some are for-profit institutions such as the University of Phoenix, based in Arizona, with a major stock portfolio on Wall Street and a presence in many of the states. Other institutions are trying to become Virtual Universities, offering distance education through the Internet anywhere in the United States and in the world. The Virtual University model offers students educational opportunities to learn across distance and independent of time schedules, something many people desire. ${ }^{5}$ Still other universities are becoming partly "corporate" by utilizing funding from business for various educational programmes and initiatives.

Many of these initiatives are controversial in the eyes of the faculty who have always believed they have autonomy within the university and total control of the curriculum. Issues to be resolved are:

- How will faculty come to terms with the many impending changes?

- How will they deal with higher production requirements?

- What will happen to tenure?

- How will this affect curriculum reform?

- How will faculty address the demand for new teaching styles?

\section{Academic Libraries at the Crossroads}

Similar to universities academic libraries are in the midst of a not so quiet revolution and have been in this state for a longer period than their parent institutions because of the electronic information explosion. During the last decade academic librarians have had to rethink how they do their work due to the fact that they had to acquire, process and balance collections of print and electronic information formats while addressing annual material inflation issues. They had to create efficient and seamless access to electronic information formats. In addition, librarians had to deal with several generations of automated library systems, from the first generation of online catalogue systems to the latest client-server, Web-based integrated library systems. Librarians have already made substantial progress in rethinking workflow; handling electronic information, and accessing and using electronic information for teaching and learning.

Thanks to their experience, librarians are emerging within the university as leaders in the electronic information environment where new formats of information and knowledge are beginning to have an impact on learning, teaching and to some extent research.

In addition to rethinking processing, academic librarians have begun to restructure public services and their role within the university. ${ }^{6}$

As pointed out earlier, there is pressure on faculty to increase their productivity and to change instructional strategies. Such demands for major revamping of academe will be difficult and will also take time. It can be accomplished if instructional teams are utilized. Such teams need to include representatives from the faculty, technology, librarians, and pedagogy. Involvement in such teams will provide librarians an opportunity to

- facilitate the integration of electronic information into the curriculum,

- offer their expertise in teaching information skills to students,

\section{- help faculty become knowledgeable about electronic information formats \\ - provide physical learning facilities for students.}

These facilities could include collaborative learning centres, state- of-the-art group study rooms, interactive teleconference centres, and computer laboratories.

In the future, the quality of academic librarians will be assessed on the basis of how they connect their customers to the information and knowledge they need, regardless of where the content may be located. ${ }^{7}$ Librarians will be assessed in terms of how well they meet the information and learning needs of the students. They will be seen as instructional partners with faculty to help students develop into effective consumers of information.

\section{Rethinking the Curriculum}

Educational reforms have been in process since the 1980 s and many faculty have been concerned about students' acquisition of knowledge and skills to think critically and be able to solve problems. Progress in educational reform to address these issues has been slow in part because faculty generally are not trained or prepared in pedagogy and instructional technology. They need assistance in integrating electronic information into teaching.

There is much pressure now on faculty members to restructure the academic curriculum in order to meet new learning needs of students. This is a very new environment for academia where curriculum development has always been the total responsibility of faculty. However, pressures from funding agencies, the business community needs, and from the present generation of students are beginning to force a more or less quiet revolution on campuses with a focus on curriculum revision. The educational enterprise is looked upon as a process of heuristic inquiry fostering programmes for further investigation. If education is to become true to its mission it must utilize access to all types of information resources throughout the learning process. Sharing of information and collaborative 
learning projects should be an integral part of every classroom experience. $^{8} \quad$ Resource-based learning in all disciplines will depend on electronic information resources and librarian involvement in teaching information skills.

\section{Information Literacy}

- is important in the higher education curriculum,

- is the key to life-long learning in work and society,

- improves the teaching and learning environment, and

- is the survival skill for the 21 st century. 9

Information literacy can constitute both a liberal as well as technical art and should become a part of the curriculum even though this will be a big challenge. Such a curriculum would have to address literacy tools in relationship to:

- electronic information such as hardware, software, computer, multimedia;

- resources such as the different types and formats of information;

- production and origin of information;

- research methodology in the computer environment;

- publishing knowledge; and

- skills to critically assess various components of information and sources. ${ }^{10}$

\section{Partnership for Information Literacy}

Librarians are in a unique position to become partners with faculty in curriculum reform and achieving resource-based learning for students. However, to achieve this new role, librarians will have to break out of their traditional reactive mode and become leaders and innovators in their interaction with faculty. 11
Resource-based learning involves active learning environments where students under the supervision of teacher/facilitators utilize a variety of information resources to solve problems. Librarians are uniquely qualified to partner with faculty to provide the resource expertise and instruction in their use. Teaching information skills will be the expertise which librarians bring to the partnership. Librarians are prepared to instruct students in finding, evaluating, organizing and applying information to problem solving. They are ready to teach students and faculty the methodology and approaches required to effectively locate and use electronic information sources. ${ }^{12}$

Librarians are collaborating with faculty in instructional development through national initiatives in the

- Association of College and Research Libraries (ACRL) Alliances for New Directions in Teaching/Learning Discussion Group,

- American Association of Higher Education (AAHE) Teaching and Learning Roundtables,

- EDUCOM's National Learning Infrastructure Initiative, and
- Coalition for Networked Information's (CNI) New Learning Communities programme.

These national collaborative groups in higher education are providing opportunities for librarians and faculty members to work together in rethinking teaching and learning. In the CNI New Learning Community programmes teams of faculty, librarians, computer experts and students are encouraged to work together to restructure courses. 13

Several impediments have been identified to be insufficient infrastructure and resources;ime commitment required to develop new courses especially with offcampus access; and copyright issues. ${ }^{14}$
Librarians have taken the initiative on many campuses to teach faculty the use of the Internet and the World Wide Web as applied to specific academic disciplines. They have sponsored department and subject specific Internet seminars to:

- introduce faculty to new information sources;

- help them set up home pages both for themselves and teaching;

- assist them to access and use electronic full-text journal databases; and

- teach them to do electronic resource sharing.

\section{Examples of Faculty- Librarian Collaboration}

There are numerous examples of faculty-librarian partnerships in higher education in the United States. They vary tremendously in complexity and scope but demonstrate that such collaboration is possible and can be effective for everyone who is a part of it.

Such partnerships do require a certain amount of entrepreneurship and creativity on the part of librarians who need to reach out to the faculty to initiate cooperative ventures. A comprehensive bibliography listing information literacy projects and related issues has been prepared by librarians at the University of MassachusettsDartmouth. ${ }^{15}$

Here are several examples of current partnerships with references to additional information.

The Information Arcade at the University of Iowa. A collaborative effort of the libraries, the information technology office and faculty resulted in the Information Arcade, a facility designed to support the use of electronic services in research, teaching, and independent learning. It includes a formal commitment to ongoing 


\section{Hannelore B. Rader}

cooperation and communication and has been in operation since the early $1990 \mathrm{~s}^{16}$

The new student-centered electronic teaching library model at California Polytechnic State University. Describes a new model for learning. It incorporates an electronic classroom, an information concourse and multimedia laboratory to accomplish student-centered learning and information competence. At present it offers a ten-week information competence class to teach competence in information use. It is a model for librarian-faculty collaboration to teach students in a new learning environment how to become competent information consumers. ${ }^{17}$

\section{The General Education Course at} California State University-San Marcos. Teaches beginning undergraduate students information literacy. It was planned jointly by librarians and faculty and after the initial teaching of the course revisions will be made based on evaluations. ${ }^{18}$

\section{The Vancouver Information} Services (VIS) Program at Washington State University Vancouver. Provides technology training for students, staff and faculty using need-based workshops including Web-based miniworkshops. ${ }^{19}$

The Interdisciplinary Computer Applications Course at Hunter College. Is based on collaborative efforts between a librarian and a philosophy professor to teach students computer applications. ${ }^{20}$

The U-wired Program at the University of Washington. Demonstrates how collaboration between librarians, computing, communications and University Extension can result in campuswide initiatives on teaching and learning. 21

New Tools to Energize Learning at Johns Hopkins University. Was developed through the team efforts of faculty from Continuing Education and the Library to expand access to library and information resources for offcampus, non-traditional graduate students. Students and faculty communicate and obtain needed resources electronically. 22

\section{The Library Liaison Program at the} University of Louisville. Has begun to build partnerships with faculty in all disciplines through collection development and collaborative efforts in bringing information literacy into the curriculum. Librarians, faculty and technology experts are partnering to teach the required general education course.

Additional examples of Web-based information literacy programmes can be found in a listing prepared by Carleton College librarians. ${ }^{23}$

\section{Suggestions for Collaboration on Instructional Programmes}

\section{Dynamic librarian-faculty} interaction is most important in order to build strong collaborative instruction programmes. Throughout the academic community in the United States there are many noteworthy efforts describing faculty-librarian partnerships in the library and higher education literature. In particular, small liberal arts colleges have made substantial progress in forming successful partnerships. 24

From the various experiences described in the library literature librarians need to be aware of the following when building partnerships between faculty and librarians:

- Plan carefully in regards to resources involving, staff, technology, facility and time.

- Know your faculty and understand the curriculum.

- Remember that faculty's role is central to ensure success.
- Understand the course content you want to work with and how information resources will fit into it.

- Utilize teams and each team member's competencies.

- Start small with pilot projects.

- Revise based on evaluation and feedback.

\section{Conclusion}

It is obvious that higher education and academic librarians are at the crossroads as they approach the millennium. Teaching and learning are undergoing major revisions and opportunities abound for librarians to collaborate with faculty in bringing about changes in the university curriculum. To be successful, librarians need to be alert, creative and informed about what is happening on their university campus. Many examples of faculty-librarian partnerships are already in existence and new ones are created every day. Librarians who started a few years ago to offer Internet workshops and technology instruction for faculty are now finding themselves in situations where faculty are seeking their advice and help in rethinking teaching. This is the situation toward which we are striving.

\section{References}

1 Vail, Peter B. Learning as a Way of Being. San Francisco: Josey-Bass, 1996.

2 Harris, Jim. The Learning Paradox. Toronto: Strategic Advantage, 1996.

3 Schwartz, Charles A. Restructuring Academic Libraries. Chicago: American Library Association, 1997.

4 Statistical Abstract of the United States 1997. Washington DC: US Department of Commerce, 1997.

5 Stallings, Dees. "The Virtual University Is Inevitable: But Will the Model Be Non-Profit or Profit? A Speculative Commentary on the Emerging Education Environment". Journal of Academic Librarianship 23:271-280(July 1997).

6 Schwartz, Charles. op. cit. 
7 Meyer, Richard W. "Surviving the Change: The Economic Paradigm of Higher Education in Transformation". Journal of Academic Librarianship 23:291-301(July 1997).

8 Nadin, Mihai. "The Civilization of Illiteracy". Educom Reziew 33:5152(March/April 1998).

9 Bruce, Christine. The Seven Faces of Information Illiteracy. Adelaide: Auslib Press, 1997.

1) Shapro, Jeremy J. "Information Technology as a Liberal Art". Educom Review 31:31-35(March/April 1996).

11 The Evolving Education Mission of the Library. Chicago: American Library Association, 1992.

12 Rader, Hannelore B. "Information Literacy and the Undergraduate Curriculum". Library Trends 44:70. 78(1995).
13 <http://www.cwru.edu/affil/cni/base/ acrlsni.htnl>.

14 More information about CNI is available from their Web site at <http://www/cni.org/projectd/nlc/ html $>$.

15 See <http://www2.lib.umassd.edu/ library $2 /$ infolit/ilbib.html $>$.

1t See <http://cause-www.niss.ac.uk/ information-resources/ir-library/ abstracts/cem9438htlm>.

17 Adalian, Paul, et. al. "The StudentCentered Electronic Teaching Library: A New Model for Learning". Reference Services Reviezw 25:11-21(1997).

is Sonntage. Gabriela and Donna M. Ohr. "The Development of a LowerDivision, General Education, CourseIntegrated Information Literacy Program". College and Resource Libraries 57:331-338(1996).
19 Diller. Karen. "Helping Your Campus Navigate Electronic Environments: Collaboration Is a Necessity". Research Strategies 15:187-192(1997).

20) Woodward. Patricia. "Librarian and Faculty Collaboration in Honors 301:88: An Interdisciplinary Computer Application Course". Research Strategies 14:132-14(1996).

21 See <http://www.cac.washington.edu/ uwired/ctlthtml $>$.

22 See <http://milyon.mdr.jhu.fru:8001/ research/education/distance/scs. html $>$.

2i See <http://www.library.carleton.edu/ instruction/loex/more.html>.

2. Dilmore. Donald H. "Librarianship/ Faculty Interaction at Nine New England Colleges". College and Research Libraries 57:274-284(1996).

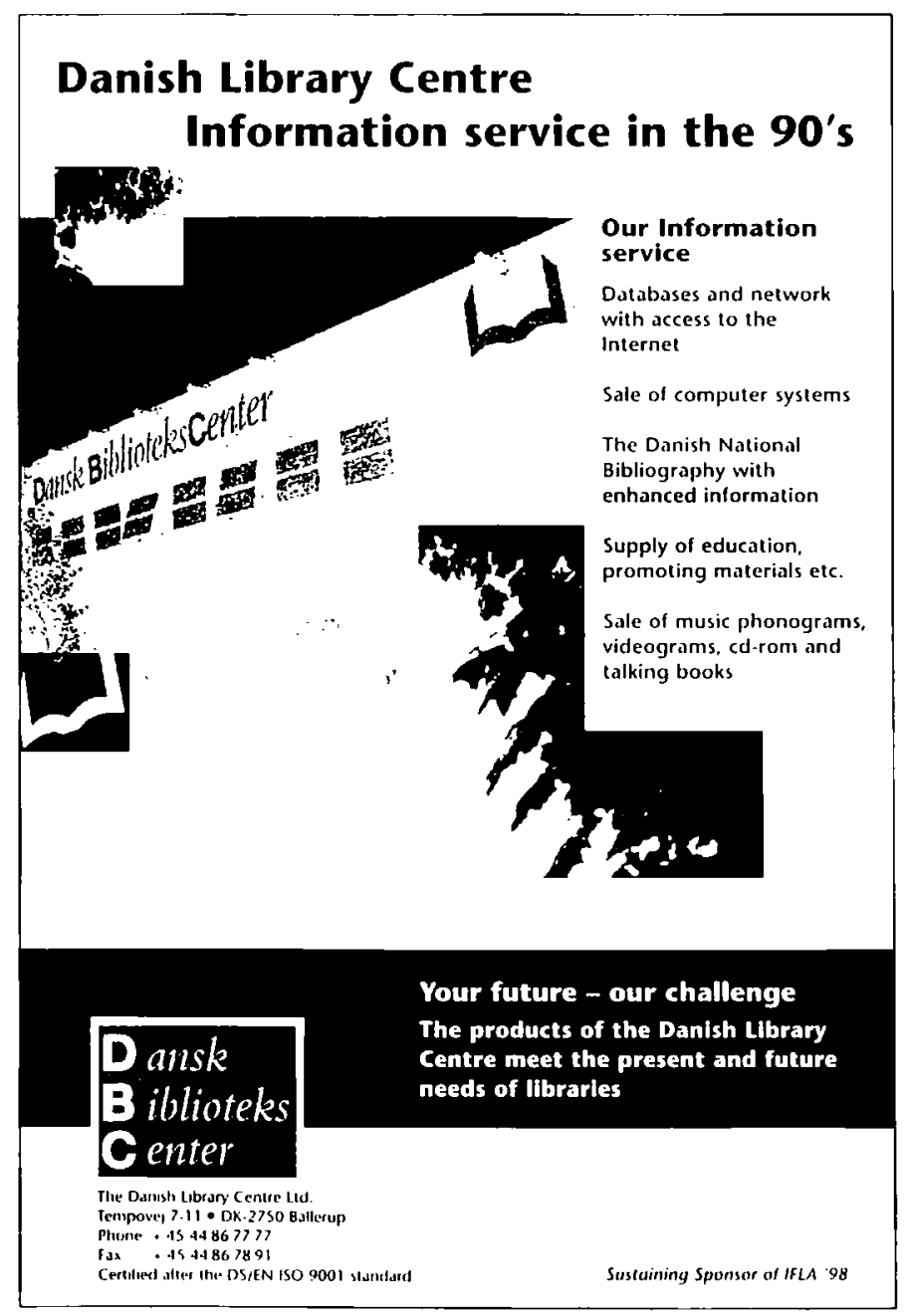

